\title{
Evaluation of the cost-effectiveness of the high- chloride vs. low-chloride crystalloid fluids in hospitalized patients from the us third-party provider perspective
}

\author{
D Makhija ${ }^{*}$, S Laplante ${ }^{1}$, I Beer ${ }^{1}$, C Schermer ${ }^{2}$, L Perrault $^{3}$ \\ From ESICM LIVES 2015 \\ Berlin, Germany. 3-7 October 2015
}

\section{Introduction}

Numerous published studies identify acute kidney injury (AKI) as an independent risk factor for developing incident chronic kidney disease (CKD), progressive CKD, end-stage renal disease (ESRD), and other important non-renal outcomes with substantial public health implications. A recent meta-analysis showed that use of highchloride crystalloids in critically ill patients was associated with a significantly higher risk of AKI (1).

\section{Objectives}

The objective of this study was to evaluate the cost-effectiveness of using high-chloride vs. low-chloride crystalloid fluids in patients hospitalized in the intensive care unit (ICU) from the US third-party provider perspective.

\section{Methods \\ A Markov decision model was developed to assess the overall impact of chronic dialysis progression, both in survivors of AKI and in patients without AKI exposed to high-chloride vs. low-chloride crystalloids over the life time horizon. The model inputs, including costs, uti- lities, and probabilities, were extracted from the pub- lished literature. The relative risk of developing AKI was obtained from the meta-analysis of published rando- mized clinical trials and observational studies mentioned above ( $\mathrm{n}=9$ studies with a total of 229 patients). The model simulated the patient outcomes, assessing the life years gained (LYG), quality-adjusted life years (QALYs), and associated health care costs.}

\section{Results}

The probability of patients developing AKI post fluid resuscitation with high-chloride crystalloids was $36 \%$ vs. $22 \%$ for patients receiving low-chloride crystalloids. At 90 days, the risk of patients progressing to chronic dialysis in AKI survivors receiving renal replacement therapy (RRT) was 88.04 per 100,000 patients in the high-chloride group vs. 53.68 per 100,000 patients in the lowchloride group. Overall costs were lower for patients receiving low-chloride crystalloids, translating into savings of $\$ 2,571$ per patient over the lifetime horizon. The incremental cost-effectiveness ratio (ICER) of -\$3,699 per QALY indicated that low-chloride crystalloids dominate (i.e. less costly and more effective) highchloride crystalloids and was well below the societal willingness-to-pay threshold of $\$ 100,000$ in the US. Various sensitivity analyses confirmed the robustness of these findings.

\section{Conclusions}

In a Markov-based decision model of patients hospitalized in the intensive care unit, low-chloride crystalloids were dominant (less costly and more effective) compared to high-chloride crystalloids. The overall impact on patients progressing to chronic dialysis and the associated costs were significantly reduced in survivors of AKI receiving low-chloride fluid resuscitation.

\section{Grant Acknowledgment}

This study was sponsored by Baxter. 


\section{Authors' details}

${ }^{1}$ Baxter Healthcare Corporation, Deerfield, United States. ${ }^{2}$ Former Baxter Healthcare Corporation Employee, Deerfield, United States. ${ }^{3}$ International Market Access Consulting, Zug, Switzerland.

Published: 1 October 2015

\section{Reference}

1. Krajewski ML, Raghunathan K, Paluszkiewicz SM, Schermer CR, Shaw AD: Meta-analysis of high- versus low-chloride content in perioperative and critical care fluid resuscitation. Br J Surg 2015 Jan, 102(1):24-36.

doi:10.1186/2197-425X-3-S1-A156

Cite this article as: Makhija et al: Evaluation of the cost-effectiveness of the high-chloride vs. low-chloride crystalloid fluids in hospitalized patients from the us third-party provider perspective. Intensive Care Medicine Experimental 2015 3(Suppl 1):A156.

\section{Submit your manuscript to a SpringerOpen ${ }^{\mathcal{O}}$ journal and benefit from:}

- Convenient online submission

- Rigorous peer review

- Immediate publication on acceptance

- Open access: articles freely available online

- High visibility within the field

- Retaining the copyright to your article

Submit your next manuscript at $\gg$ springeropen.com 